\title{
The Potentiality of Women Entrepreneurs in Bangladesh with Special Reference to Sylhet Region
}

\section{Sakufa Chowdhury ${ }^{1}$, Md. Mizanur Rahman ${ }^{2}$}

\author{
${ }^{1}$ Assistant Professor, Department of Business Administration, Shahjalal University of Science \& \\ Technology, BANGLADESH \\ ${ }^{2}$ Graduate Student, Department of Business Administration, Shahjalal University of Science \& \\ Technology, BANGLADESH
}

\begin{abstract}
This paper justifies the potentiality of the women entrepreneurs in Bangladesh. For this purpose, Sylhet is taken as a study area which can be the prospective sectors for the women entrepreneurs. Huge amount of foreign remittance comes here from abroad that can be utilized in this sector successfully, and the mindset of people are not so fundamental. All of these issues are supporting to work in this region. Besides these, studying in this sector it is found that the women entrepreneurs of this region are more industrious, self-confident, dynamic, ambitious, adaptable and possess risk taking capacity and last but not the least are creative and innovative. It is obviously profitable sector which is clear after analyzing the data. Attempts also have been made here to find out the characteristics and the contributions of the women entrepreneurs to prove themselves not only as the emerging tigers but also as the economically empowered, solvent, respected and above all a contributor in the national income in this third world country, the obstacles they are facing and also the probable solutions in this context.
\end{abstract}

Keyword: Entrepreneurship, Women, Empowerment, SME, Sylhet JEL Classification Code: M100, M130

\section{INTRODUCTION}

Women entrepreneurship in Sylhet is not an of late topic. Though women entrepreneurs were active in Sylhet twenty years ago, they were not that much familiar with the concept of entrepreneurship those days. At first they used to perform their activities only for earning or showing creativity. But the radical change occurred when Women Chamber of Commerce and Industries opened their cell in Sylhet, probably at the beginning of the year 2002. At the very outset, there were only 3-5 members, and now it's enriched with 28 women enterprises, in total near about 100 (including registered and unregistered). Now-a-days, women entrepreneurs of Bangladesh are also in action to empower women entrepreneurs. 
Sylhet is the highest foreign remittance earning area in Bangladesh because near about half a million people of this area are now living in abroad. So, in a sense, people are more solvent than other areas and the availability of the fund is easy to run a business. As a result, women in Sylhet are interested to utilize the fund and want to make their status. A thorough analysis has been done to find out the potentiality of these womenfolk. In this paper we try to explores the social and economic empowerment through an in-depth analysis of how these women entrepreneurs view and experience their earnings and of the associated problems (if there is any) they face in their day-to-day affairs.

\section{LITERATURE REVIEW}

The women entrepreneurship is a recent concept with very emerging power in the world and it has been designed for the development of the condition of the women and it's also work as a locomotive for the economic development of the country (Vossenberg, 2013). In Bangladesh women entrepreneur have come a long way in breaking the barriers of social conventions and stereotyping that have kept women outside of business though in first phase they work only for survival (Haidar \& Akhtar, 1999). But they face severe constraints in terms of lack of access to capital, managerial and quality control skills, basic knowledge about the industry and market and of course, access to markets (World Bank, 2003). They also have shortage of knowledge measure the risk associated with business which is the key indicator of women entrepreneurship development (Rahman, Hossain, \& Miah, 2000). Women entrepreneur in Bangladesh are the most disadvantaged group in the society - the women and they were challenging each step to overcome the obstacles and come into the light. A lot of hindrances are surrounded in their way of empowerment. There are some prospective sectors where women can enter as an entrepreneur and empower themselves (Chowdhury, 2001). And the success and failure of entrepreneurs are affected by personal attributes (Ahktaruddin, 1999) but (Ahktaruddin, 2000) focused on the social and economic attribute of the entrepreneurs. Anyway, the impressive success of women entrepreneurship stakeholders indicate that as in important 'untapped source' of economic growth and development (Minniti \& Naudé, 2010) and others stated "forget aid, focus on foreign investment in women entrepreneurs as key drivers for growth and development" (Isaac, 2012).

\section{OBJectives}

The primary objective of our study is to identify the potentiality of women entrepreneurs in Sylhet region. The other objectives are:

- To sort out the basic features, those are mandatory for the women entrepreneurs' potentiality.

- To find out the problem and prospects of women entrepreneurs.

- $\quad$ To suggest policies as remedial measures.

\section{HYPOTHESIS}

Hypothesis development is very crucial because the acceptance and rejection of the hypothesis show the significance of the study. The potentiality of women entrepreneurship is affected by the profit of the business. Therefore, our hypotheses are:

$H_{0}$ : Women entrepreneurs in Sylhet city are not getting any profit from their business.

$H_{1}$ : Women Entrepreneurs in Sylhet are getting profit from their business. 


\section{Methodology}

The methodology of the study is based on triangulation method and for those we consider 40 (for scenario analysis) and 90 (to justify the potentiality) women entrepreneur from Sylhet region as our sample on the basis of judgmental sampling. A semi-structured question with 21 items used for data collection and along case study and opinion survey method has also been used to collect information. Hypothesis test and grading systems are used to analyze the data.

\section{Case Study on Women Entrepreneurs}

Some selected cases are presented here to represent the scenario and also the factors behind their working inspiration.

\section{Case Study 1}

Fatema Chowdhury and Shorna Dey, the owner of Women Fashion World \& Beauty Parlor engaging in boutiques and beauty parlor with own showroom. There are 35 employee works in this firm, and they design their own product. They started the business with Tk. 8-9 lakh (own finance, no loan) and now their investment is Tk. 15 laks and not yet no loan is taken. In the near future, they try to expand the business. They already received "Onnodin Magazine- Shressto Sharee" award for their success in business. Their success rate 15-20\% with profit and both upper class and middle-class people are listed as their customer. Creativity were the main factors that was inspired her to do such kind of business.

\section{Case Study 2}

Shumoti Sinha the owner of Rumki Manipuri Shareeghar engaging business in Manipuri Handloom with own showroom. There are a few employee works in this firm, and they design their product. They started the business with Tk. 5,0000 with own finance, no loan and now their investment is above Tk. 2 lakh, loan taken from BRAC Bank and Bangladesh Krishi Bank. In the near future, she will try to expand the business. The available products are-own sewing dresses, handicrafts, bed sheets, mufflers, shawls, etc. In this firm product, price is fixed and demand increase in winter season. She received full family support for her business. Her business success rate $5 \%$ with profit and both upper class and middle-class people are listed as her customer. Tradition, creativity and financial independence were the main factors that were inspired her to do such kind of business.

\section{Case Study 3}

Salma Begum engaging business in Farm and Poultry. There are 25 employee works here. They started the business with Tk. 30,000 with own finance, no loan, and now their investment is above Tk. 2 lakh, loan taken from Bangladesh Krishi Bank. In the near future she will try to expand the business. The available products are - milk and Ox. She received full family support for her business. She is currently making loss in her business. Financial independence was the main factor that was inspired her to do such kind of business.

Findings form Case Study: The studied women enterprises are located in the feasible location with their identities. They differentiate with each other with their distinct designs, products and prices. Not all but about 30\% women entrepreneurs run their business with own finance with a skilled group of people. The factors behind their works are to show their creativity, selfindependence, to raise their living standard, etc. Their family support also helped them to run ahead. So from this survey it is clear that women are successfully running their business here and male partners play a constructive and supportive role behind them. 


\section{SCENARIO ANALYSIS}

Scenario analysis of the study have been summarized in the following table: Table 1 shows that, among 40 samples $25 \%$ are engaged on Boutiques and Parlor, $37.5 \%$ are on Tailoring and Handicrafts, $20 \%$ on Manipuri Handloom, $7.5 \%$ are on Cane and Bamboo Articles, 5\% are on Dairy and Poultry, and 5\% are on Homemade Snacks and Fast Food.

Table 1: Percentage Rate of the Different Samples

\begin{tabular}{|l|c|c|}
\hline Types Of Women Entrepreneurs & Number of Observations & Percentage Rate \\
\hline Boutiques and Parlor & 10 & $25 \%$ \\
\hline Tailoring and Handicrafts & 15 & $37.5 \%$ \\
\hline Manipuri Handloom & 8 & $20 \%$ \\
\hline Cane and Bamboo Articles & 3 & $7.5 \%$ \\
\hline Dairy and Poultry Farms & 2 & $5 \%$ \\
\hline Homemade Snacks and Fast Food & 2 & $5 \%$ \\
\hline Total Number of Observation/Sample & 40 & 100 \\
\hline
\end{tabular}

(Source: Field Survey)

Table 2 shows that, profit motive, the highest priority goes to Tailoring and Handicrafts with high profits investing small amount (50\% profit), then comes Manipuri Handloom (25\% profit without any promotion), then comes Homemade Snacks and Fast Food (20\% profit, investing a very small amount without any promotional tool), after that comes Boutiques and Parlor (20\% profit, required a large amount involving promotional tools) and at last comes the Dairy and Poultry Farms (5\% profit).

Table 2: Summary of the Survey Results

\begin{tabular}{|c|c|c|c|c|c|c|}
\hline Features & $\begin{array}{l}\text { Boutiques } \\
\text { and Parlor }\end{array}$ & $\begin{array}{c}\text { Manipuri } \\
\text { Handloom }\end{array}$ & $\begin{array}{c}\text { Tailoring and } \\
\text { Handicrafts }\end{array}$ & $\begin{array}{c}\text { Cane and } \\
\text { Bamboo } \\
\text { Articles }\end{array}$ & $\begin{array}{c}\text { Dairy and } \\
\text { Poultry Farms }\end{array}$ & $\begin{array}{c}\text { Homemade } \\
\text { Snacks and } \\
\text { Fast Food }\end{array}$ \\
\hline Initial Investment & $\begin{array}{c}\text { Tk.500,000 } \\
-700,000\end{array}$ & $\begin{array}{l}\text { Tk. } 20,000 \\
-50,000\end{array}$ & $\begin{array}{c}\text { Tk. } 15,000 \\
-30,000\end{array}$ & $\begin{array}{l}\text { Tk. } 5,000 \\
-10,000\end{array}$ & $\begin{array}{c}\text { Tk. } 20,000 \\
-50,000\end{array}$ & $\begin{array}{l}\text { Tk. } 5,000 \\
-7,000\end{array}$ \\
\hline Sources of Fund & Own Finance & $\begin{array}{c}\text { Loan }+ \\
\text { Own Finance }\end{array}$ & $\begin{array}{c}\text { Loan }+ \\
\text { Own Finance }\end{array}$ & Loan & \begin{tabular}{|c|}
$\begin{array}{c}\text { Own Finance } \\
+ \text { Loan }\end{array}$ \\
\end{tabular} & Own Finance \\
\hline Annual Turnover & $\begin{array}{c}\text { Above } \\
\text { Tk. } 600,000\end{array}$ & $\begin{array}{c}\text { Above } \\
\text { Tk. } 25,000\end{array}$ & $\begin{array}{c}\text { Above } \\
\text { Tk. } 22,500\end{array}$ & \begin{tabular}{|c|} 
No profit, \\
sometime loss
\end{tabular} & $\begin{array}{c}\text { Above } \\
\text { Tk. } 21,000\end{array}$ & $\begin{array}{c}\text { Near about } \\
\text { Tk. 6,000 }\end{array}$ \\
\hline Percentage of Profit & $20 \%$ & $25 \%$ & $50 \%$ & $0 \%$ & $5 \%$ & $20 \%$ \\
\hline Edge over Competitors & $8(80 \%)$ & $5(60-65 \%)$ & $100 \%$ & \begin{tabular}{|c|} 
No \\
Competencies \\
\end{tabular} & $\begin{array}{c}\text { No } \\
\text { Competencies }\end{array}$ & $2(100 \%)$ \\
\hline Promotional Tool Used & Yes & No & Yes & No & No & No \\
\hline $\begin{array}{l}\text { Time Consumed } \\
\text { in Promoting }\end{array}$ & 3-6 Months & 0 & 2-4 Months & 0 & 0 & 0 \\
\hline
\end{tabular}

(Source: Field Survey)

Table 3: Earning Range of the Surveyed Sample

\begin{tabular}{|l|c|c|}
\hline Types of Women Entrepreneurs & No. of Observations & Daily Earnings Level (Tk.) \\
\hline Cane and Bamboo Articles & 3 & $0-200$ \\
\hline Dairy and Poultry Farms & 2 & $200-400$ \\
\hline Homemade Snacks and Fast Food & 2 & $400-600$ \\
\hline Manipuri Handloom & 8 & $600-800$ \\
\hline Tailoring and Handicrafts & 15 & $800-1,000$ \\
\hline Boutiques and Parlor & 10 & $1,000-1,200$ \\
\hline Total Number of Observation/Sample & \multicolumn{2}{|c|}{40} \\
\hline
\end{tabular}

(Source: Field Survey) 


\section{Result of Hypothesis Test}

All indicator of scenario analysis (Table 3) show that, women entrepreneurs is promising in Sylhet region and the evidence from Appendix 2 also indicates that following consequence:

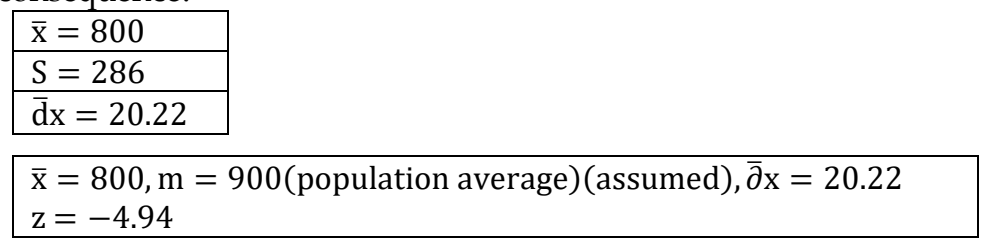

As we seen, from the above-computed value of $z$ is greater than the table value of $z= \pm 1.96$ at $5 \%$ level of significance, therefore, the hypothesis is $\mathrm{H}_{0}$ rejected and $\mathrm{H}_{1}$ is accepted. $\mathrm{H}_{1}$ is accepted; it means the data and the results are significant of our second hypothesis.

\section{Justifying the Potentiality of Women Entrepreneurs}

To justifying the potentiality of women entrepreneurship we use comparative test results of three types of women entrepreneurs' model (Islam \& Mamun, 2000). After applying the model, we can found out a causal relationship of the factors corresponding higher grades that characterize the successful entrepreneurs which are later mentioned as 'potential entrepreneurs.'

Table 4: Comparative Test Results of Three types of Women Entrepreneurs

\begin{tabular}{|c|c|c|c|c|c|c|c|c|c|c|c|c|c|c|c|c|}
\hline \multirow{3}{*}{$\begin{array}{l}\text { Characteristics of } \\
\text { Entrepreneurs }\end{array}$} & \multicolumn{12}{|c|}{ Applicability for Different Categories } & \multirow{2}{*}{\multicolumn{3}{|c|}{$\begin{array}{c}\text { Index of categories } \\
(0-3 \text { scale })\end{array}$}} & \multirow{3}{*}{$\begin{array}{c}\text { Index of } \\
\text { Total Samples } \\
(0-3) \text { scale }\end{array}$} \\
\hline & \multicolumn{3}{|c|}{ High (3) } & \multicolumn{3}{|c|}{ Medium (2) } & \multicolumn{3}{|c|}{ Low (1) } & \multicolumn{3}{|c|}{ No $(0)$} & & & & \\
\hline & $\mathrm{A}$ & $\mathrm{B}$ & C & A & $\mathrm{B}$ & $\mathrm{C}$ & A & B & $\mathrm{C}$ & A & B & C & A & B & $\mathrm{C}$ & \\
\hline Need for Achievement & 20 & 15 & 10 & 10 & 10 & 10 & 0 & 5 & 10 & 0 & 0 & 0 & 2.7 & 2.3 & 2 & 2.33 \\
\hline Need for Power & 15 & 15 & 25 & 7 & 10 & 5 & 4 & 5 & 0 & 4 & 0 & 0 & 2.1 & 2.3 & 2.8 & 2.4 \\
\hline Risk Taken & 20 & 25 & 18 & 5 & 5 & 5 & 5 & 0 & 4 & 0 & 0 & 0 & 2.5 & 2.8 & 2.3 & 2.5 \\
\hline Internal Locus of Control & 25 & 15 & 5 & 5 & 5 & 5 & 0 & 10 & 15 & 0 & 0 & 5 & 2.8 & 1.7 & 1.3 & 1.93 \\
\hline External Locus of Control & 5 & 10 & 15 & 12 & 10 & 5 & 8 & 5 & 5 & 5 & 5 & 5 & 1.6 & 1.8 & 2 & 1.8 \\
\hline Creativity and Innovation & 20 & 25 & 10 & 10 & 5 & 5 & 0 & 0 & 10 & 0 & 0 & 5 & 2.7 & 2.8 & 1.8 & 2.43 \\
\hline Need for Autonomy & 13 & 25 & 15 & 9 & 5 & 10 & 2 & 0 & 5 & 6 & 0 & 0 & 1.96 & 2.8 & 2.2 & 2.32 \\
\hline Self Confidence & 25 & 25 & 20 & 5 & 5 & 10 & 0 & 0 & 0 & 0 & 0 & 0 & 2.8 & 2.8 & 2.7 & 2.77 \\
\hline Leadership Capability & 5 & 20 & 0 & 5 & 10 & 20 & 5 & 0 & 10 & 15 & 0 & 0 & 1 & 2.7 & 1.7 & 1.8 \\
\hline Industriousness & 30 & 30 & 30 & 0 & 0 & 0 & 0 & 0 & 0 & 0 & 0 & 0 & 3 & 3 & 3 & 3 \\
\hline Opportunity Seeking & 3 & 20 & 10 & 10 & 5 & 15 & 8 & 5 & 0 & 9 & 0 & 5 & 1.2 & 2.5 & 2 & 2 \\
\hline Decision Making Capability & 6 & 15 & 5 & 5 & 10 & 10 & 4 & 5 & 0 & 15 & 0 & 15 & 1.1 & 2.3 & 1.2 & 1.53 \\
\hline Adaptability & 25 & 30 & 8 & 5 & 0 & 15 & 0 & 0 & 5 & 0 & 0 & 2 & 2.8 & 3 & 1.96 & 2.57 \\
\hline Foresightedness & 8 & 15 & 10 & 10 & 15 & 0 & 5 & 0 & 10 & 7 & 0 & 10 & 1.63 & 2.5 & 2.3 & 2.14 \\
\hline Dynamism & 25 & 25 & 20 & 5 & 5 & 5 & 0 & 0 & 5 & 0 & 0 & 0 & 2.8 & 2.8 & 2.5 & 2.71 \\
\hline Ambition & 25 & 20 & 20 & 5 & 5 & 5 & 0 & 5 & 5 & 0 & 0 & 0 & 2.8 & 2.5 & 2.5 & 2.6 \\
\hline Education \& Training & 10 & 10 & 5 & 10 & 10 & 5 & 5 & 5 & 15 & 5 & 5 & 5 & 2 & 1.8 & 1.3 & 1.7 \\
\hline
\end{tabular}

(Source: Field Survey)

Note: A- Entrepreneurs engaged in boutiques and parlor.

B - Entrepreneurs engaged in Manipuri handloom.

C- Entrepreneurs engaged in tailoring and others (making cane and bamboo articles, poultry and farm, homemade snacks and fast foods etc.).

The consolidated results regarding the characteristics of entrepreneurs show that Industriousness (3.00), Self-confidence (2.77), Dynamism (2.71), Ambition (2.6) and Adaptability (2.57) are the most important characteristics. These are followed by Risk taking capacity (2.5), Creativity and Innovation (2.43), Need for Power (2.4), Need for Achievement (2.33), Need for Autonomy (2.32), Foresightedness (2.14), Opportunity Seeking (2), Internal Locus of Control (1.93), External Locus of Control (1.8), Leadership Capability (1.8), Education and Training (1.7), Decision-making Capacity (1.53). 
Interestingly, it is observed that the category-wise applicability of entrepreneurship characteristics is found a little different for different businesses. The findings are enumerated in Table 5.

Table 5: Category-Wise Applicability of Women Entrepreneurship Characteristics

\begin{tabular}{|c|c|c|c|}
\hline \multirow[t]{2}{*}{ Category } & \multicolumn{3}{|c|}{ Applicability emphasis } \\
\hline & $\operatorname{High}(>2-3)$ & $\operatorname{Medium}(>1-2)$ & $\operatorname{Low}(>0-1)$ \\
\hline $\begin{array}{l}\text { Boutiques } \\
\text { and Parlor }\end{array}$ & $\begin{array}{c}\text { Industriousness, self-confidence, } \\
\text { dynamism, adaptability, ambition, } \\
\text { internal locus of control, creativity } \\
\text { and innovation, need for } \\
\text { achievement and risk taking } \\
\text { capacity. }\end{array}$ & $\begin{array}{l}\text { Education and training, need for } \\
\text { autonomy, foresightedness, } \\
\text { external locus of control, } \\
\text { opportunity seeking and } \\
\text { decision-making capability. }\end{array}$ & $\begin{array}{l}\text { Leadership } \\
\text { Capability }\end{array}$ \\
\hline $\begin{array}{l}\text { Manipuri } \\
\text { Handloom }\end{array}$ & $\begin{array}{c}\text { Industriousness, adaptability, } \\
\text { dynamism, self-confidence, } \\
\text { creativity and innovation, need for } \\
\text { autonomy, risk taking capacity, } \\
\text { leadership capability, ambition, } \\
\text { opportunity seeking, } \\
\text { foresightedness, ambition, need for } \\
\text { power, decision making capability, } \\
\text { need for achievement. }\end{array}$ & $\begin{array}{l}\text { Education and training, external } \\
\text { locus of control, internal locus of } \\
\text { control. }\end{array}$ & No \\
\hline $\begin{array}{l}\text { Tailoring } \\
\text { and others }\end{array}$ & $\begin{array}{l}\text { Industriousness, need for power, } \\
\text { self-confidence, need for autonomy, } \\
\text { dynamism, ambition, risk taking } \\
\text { capacity, foresightedness. }\end{array}$ & $\begin{array}{l}\text { Need for achievement, opportunity } \\
\text { seeking, external locus of control, } \\
\text { adaptability, creativity and innovation, } \\
\text { leadership capability, internal locus of } \\
\text { control, education and training, } \\
\text { decision-making capability. }\end{array}$ & No \\
\hline
\end{tabular}

(Source: Field Survey)

Findings of Justifying the Potentiality: From the above study it is found that Industriousness, Self-confidence, Dynamism, Ambition and Adaptability are scoring the maximum grades. These are followed by Risk taking capacity and Creativity and innovation. All of these factors are essential to be a potential women entrepreneur, and the study supports this. Besides these, if we go through the category-wise applicability of women entrepreneurship characteristics we can also find out that all the categories such as Boutiques and Parlors, Manipuri handloom, tailoring and others are the dynamic sectors and also giving the highest priority to the factors Industriousness, Self-confidence, Dynamism, Ambition, Adaptability, Risk taking capacity, and Creativity and Innovation. Thus, the result produced here indicates that women entrepreneurs involved in these sectors are potential and they can run the organization successfully.

\section{THE POSSIBILITIES OF WOMEN ENTREPRENEURSHIP}

- Sylhet is the highest foreign remittance earning area in Bangladesh because near about half a million of people of this area are now living in abroad, and they send a huge amount of remittance every year. Women of this region can utilize the fund and can make their business enterprises.

- The enterprises that are made by the women not only to make them solvent or financially independent but also to create job opportunities for others (both male and female).

- In Sylhet, at least one member from each family lives in abroad, and the family depends upon that member usually. In this situation, it is easy to for the women entrepreneurs to acquire the fund and because of that they do not need to take the loan from a bank or other financial institutions. 
- Sylhet is not a big city. The enterprises are located in central areas normally in Zindabazar, Aamborkhana, Shubidbazar, Lamabazar and in Naiorpul. One can reach these areas easily, and it does not take too much cost. That is the locations are convenient.

- People of this region believe in relationship marketing. If one can build and maintain good communication and relation with her customers, it will create long-term value to customers on her account and will also achieve customer satisfaction. Thus, a good number of customers can be built easily.

\section{THE PROBLEMS IN WOMEN ENTREPRENEURSHIP}

Women are not free from their daily household life. But the question here is that why should they go outside to do the work, also maintaining the household work also. Obviously it is not the case. However, the hindrances that the women entrepreneurs are facing are-

- Women are not secure in outside the house. Each and every moment they are getting physical abuse, sexual harassment, etc. Even that the educated people also talk in bad order if they come home at late night. Because, it is against their so called tradition.

- The traditional believe of the people that, they think women are 'needed at home' to look after the family. They also argue that a 'women touch' is necessary for raising children. Others say that "wife" have no close substitutes. Increased women participation in the business field makes them less dependent on their husbands. As a result, they also get the role of decision making.

- The industry dominated by male middlemen suppliers, contractors and exporters and they also take benefit of women's remoteness in the residence and lack of access to credit, supplies and information about the financial system of their work.

- Because of physical structure women frequently encounter "mastans" (hand looms) rowdy males, whom they find hard to tackle and are stressed to give money on require.

- In trade women entrepreneurs are cheated by their male partner through dishonest means that may revolve risky when apt to encounter.

- Scarcity of proficient or skilled labor, deficiency of market facilities for women entrepreneurs and deficiency of appropriate sales centre are some of the major barrier to flat transactions in business.

- The women entrepreneurs face lack of storing facilities and space they suffer grave problems through damage or stealing of the products. Various problems related to low payment also created by middlemen.

- Insufficiency of capital is a key problem and where offered the high-interest rates daunt investment. Lenders are less interested to provide them money because of two reasons - firstly, women do not have properties in their own name to use them as security for acquiring funds and secondly, the financial institutions regard them less credit worthy and also think that they can depart the business any time.

- Women observing "purdah"(seclusion) frequently find it hard to visit banks, buy their inputs or raw materials or market their product in open settings where they would have to covenant with men.

- Male's reservation is a major problem for women. Because of male's reservation women suffer about woman's position, skill and competence and are treated accordingly. Male's reservation also creates a strong barrier for women to entry into a business.

- Government SME policy is not very favorable for the women entrepreneurs. Though women entrepreneurs starts their business on the basis of SME idea. 


\section{Policy Suggestions}

What has been apparent from the foregoing discussion is unwarranted and highly horrible. Evidently, in spite of their significant contribution to the advancement of the economy, they have no respite of their longstanding insurmountable sufferings. Ironically our policy planners have not shed necessary light on the underlying factors behind the problems that directly or indirectly inhibit the growth, prosperity and enhancement of these women. It is, therefore, this paper articulately proposes the following policy suggestions to be adopted in order to avert each of the aforesaid problems.

- Pragmatic programs to build social awareness about the significant and crucial role the women entrepreneur play in the development of the country are to be devised and implemented, and their progress be regularly monitored in order to so alter the ancient, outdated mindset of the general people that instead of being suspicious of the nature of the women entrepreneurs, the society as a whole do respect and take care of these unsung heroines of the country.

- Women entrepreneur should focus on the following matters -

$\checkmark \quad$ Everything in the beginning does not go on favor of any entrepreneur. So every women entrepreneur should have enough patience to carry on.

$\checkmark \quad$ Every women entrepreneur should develop a long term vision to success.

$\checkmark$ Ambition is regarded as an inspiring fact to be a successful women entrepreneur.

$\checkmark$ Honesty and integrity smooth the way to success.

$\checkmark$ Hardworking ability boosts the confidence of women entrepreneur.

$\checkmark$ Family inspiration never let them down.

- Ensure the credit facility, training facilities, market facilities and proper assistance can help rural women entrepreneurs.

- On stop service in banks for women entrepreneur with high-quality service.

- Arrangement of exclusive fairs to promote products manufactured by small and cottage based units. Also need to ensure fixed quota of stalls for women entrepreneurs at export fairs. And provide special market facilities both in the domestic and the international arena.

- Government should ensure the other factors of the market stability to control the price hikes of raw materials.

\section{CONCLUSION}

There are lots of problems in this region, but the possibilities are not few. It is agreed that now women are the parts of the stakeholders of the country's economy working in close cooperation with others. They are not 'abala' (weak). So, we should check all the evil thought and things that go against these heroines. We should keep pressure on the law and enforcement agency and also on the government to compel them to take necessary steps as early as possible in enhancing their business and also to remove all obstacles. If the woman entrepreneurs are empowered, the whole women folk of the country will be empowered. In this bond, we should accept our strategic vision and develop advance steps. There is no longer any time to talk about women entrepreneurship and their empowerment. It is high time to do smoothing about women entrepreneurship and their empowerment. 


\section{REFERENCE}

Ahktaruddin, M. (1999). A Case study of some Successful and Unsuccessful Entrepreneurs in Bangladesh. Journal of Business Administration.

Ahktaruddin, M. (2000). Socio-Economic Profile of Industrial Entrepreneurs: A Study on North Region of Bangladesh. Journal of Banking and Finance.

Chowdhury, M. M. (2001). The Emerging Women Entrepreneurs of Bangladesh. FBCCI Journal.

Gupta, S., \& Gupta, M. (2005). Business Statistics (14th Edition ed.). New Delhi: Suntan Chand \& Sons.

Haidar, R., \& Akhtar, R. (1999). The Role of NGO and Women's Perception of Empowerment: An Anthropological Study in a Village. Journal of Women for Women, 6, 78-86.

Isaac, C. (2012, June 7). Forget Foreign Aid, Focus on Foreign Investment In Women Entrepreneurs. New York, United States of America: Forbes.

Islam, N., \& Mamun, M. Z. (2000). Entrepreneurship Development: An Operational Approach: Text and Cases with Special Reference to Bangladesh. Dhaka: University Press, Limited.

Minniti, M., \& Naudé, W. (2010). What Do We Know About The Patterns and Determinants of Female Entrepreneurship Across Countries? European Journal of Development Research.

Rahman, M. M., Hossain, M. I., \& Miah, A. S. (2000). Problems of Women Entrepreneurship Development: A Study of Grameen Bank Finance on Some Selected Areas. Islamic University Studies (Part-C) , 3, 124-128.

Vossenberg, S. (2013). Women Entrepreneurship Promotion in Developing Countries: What explains the gender gap in entrepreneurship and how to close it? Maastricht School of Management.

World Bank. (2003). South Asia Enterprise Development Facility - 2003 Annual Report. Washington, DC. 
APPENDIX 1

'Z' Table

\begin{tabular}{|c|c|c|c|c|c|}
\hline Level of Significance & $\mathbf{0 . 1 0}$ & $\mathbf{0 . 0 5}$ & $\mathbf{0 . 0 1}$ & $\mathbf{0 . 0 0 5}$ & $\mathbf{0 . 0 0 0 2}$ \\
\hline Critical value of $\mathrm{z}$ for One-Tailed Test & -1.28 or 1.28 & -1.645 or 1.645 & -2.33 or 2.33 & -2.58 or 2.58 & -2.88 or 2.88 \\
\hline Critical value of $\mathrm{z}$ for Two-Tailed Test & -1.645 or 1.645 & -1.96 or 1.96 & -2.58 or 2.58 & -2.81 or 2.81 & -3.08 or 3.08 \\
\hline
\end{tabular}

Source: (Gupta \& Gupta, Business Statistics, 2005)

\section{APPENDIX 2: Statistical Calculation}

\section{Frequency Table}

\begin{tabular}{|c|c|c|c|c|c|}
\hline Range & $\mathbf{x}$ (midpoint) & $\mathbf{f}($ frequency) & $\mathbf{( x - 7 0 0 ) / 2 0 0 ~ = d ~}$ & $\mathbf{f d}$ & $\mathbf{f d}^{2}$ \\
\hline $0-200$ & 100 & 3 & -3 & -9 & 27 \\
\hline $200-400$ & 300 & 2 & -2 & -4 & 8 \\
\hline $400-600$ & 500 & 2 & -1 & -2 & 2 \\
\hline $600-800$ & 700 & 8 & 0 & 0 & 0 \\
\hline $800-1,000$ & 900 & 15 & +1 & +15 & 15 \\
\hline $1,000-1,200$ & 1,100 & 10 & +2 & +20 & 40 \\
\hline \multicolumn{7}{|c|}{$\mathrm{N}=40$} & $\mathrm{fd}=20 \quad \sum \mathrm{fd}^{2}=92$ \\
\hline
\end{tabular}

$$
\begin{aligned}
\bar{x} & =A+\left(\sum f d / n\right) * i \quad \text { where }, \bar{x}=\text { mean, } A=\text { average }, i=\text { class range } \\
& =700+(20 / 40) * 200=800
\end{aligned}
$$$$
S=\sqrt{ }\left\{\left(\sum f d^{2} / n\right)-\left(\sum \mathrm{fd} / \mathrm{n}\right)^{2}\right\} * \mathrm{i} \quad \text { where, } S=\text { standard deviation }
$$$$
=\sqrt{ }\left\{(92 / 40)-(20 / 40)^{2}\right\} * 200=\sqrt{ }\{2.3-0.25\} * 200
$$$$
=(1.43) * 200=286
$$

And standard error of the mean, $\bar{\partial} x=286 / \sqrt{200}=\mathbf{2 0 . 2 2}$

Let us take the null hypothesis that entrepreneurs in Sylhet city are not getting any profit.

$\bar{x}=800, m=900$ (population average)(assumed), $\bar{\partial} x=20.22$

$z=(\bar{x}-m) / \bar{\partial} x=(800-900) / 20.22=-4.94$

Since, computed the value of $z$ is greater than the table value of $z= \pm 1.96$ at $5 \%$ level of significance therefore, the null hypothesis is rejected. Hence, the entrepreneurs in Sylhet city are getting profit. 